\title{
Teacher Basic Skills in Learning Science in Junior High Schools Facing the $21^{\text {st }}$ Century
}

\author{
Muhlis H. Usman ${ }^{1,2 *}$, Agil Al Idrus ${ }^{1,2}$, Aris Doyan ${ }^{1,3}$, Harry Soeprianto1,4, Aliefman Hakim¹, 5 \\ ${ }^{1}$ Master of Science Education Program, Postgraduate, University of Mataram, Lombok, West Nusa Tenggara, Indonesia \\ 2 Biology Education Study Program, Faculty of Teacher Training and Education, University of Mataram, Lombok, West Nusa Tenggara, \\ Indonesia \\ ${ }^{3}$ Physics Education Study Program, Faculty of Teacher Training and Education, University of Mataram, Lombok, West Nusa Tenggara, \\ Indonesia \\ ${ }^{4}$ Mathematics Education Study Program, Faculty of Teacher Training and Education, University of Mataram, Lombok, West Nusa \\ Tenggara, Indonesia \\ ${ }^{5}$ Chemistry Education Study Program, Faculty of Teacher Training and Education, University of Mataram, Lombok, West Nusa Tenggara, \\ Indonesia
}

DOI: $10.29303 /$ jppipa.v7i3.652

\section{Article Info}

Received: Februari 15th, 2021

Revised: May 27th, 2021

Accepted: May 29th, 2021

\begin{abstract}
This study aims to determine the level of teacher skills in science learning in junior high schools facing the $21^{\text {st }}$ century, especially the basic teaching skills of teachers. The research examined consisted of two types of data, namely qualitative and quantitative from the eight basic skills of teachers. The qualitative and quantitative data were interpreted and obtained information from the group discussion forums. The results show that the level of basic teaching skills for science teachers in Mataram City Junior High School is $33.4 \%$ very good, $60 \%$ in a good position, $6.6 \%$ at a sufficient level. Meanwhile, of the eight basic teaching skills of science teachers, the skills to open lessons and various teaching skills for junior high school science teachers in Mataram have very good skills, while explaining skills are still lacking, and basic teaching skills in very good categories are found in junior high school science teachers who are senior or already occupying a position. Coach level IV/a and above.
\end{abstract}

Keywords: Basic teacher skills; Learning science; the $21^{\text {st }}$ century

Citation: Usman, M.H., Al Idrus, A., Doyan, A., Soeprianto, H., \& Hakim, A. (2021). Teacher Basic Skills in Learning Science in Junior High Schools Facing the 21st Century. Jurnal Penelitian Pendidikan IPA, 7(3), 331-334. doi:https://doi.org/10.29303/ippipa.v7i3.652

\section{Introduction}

Indonesia needs complete human resources. Humans are intelligent, healthy, honest, have noble character, have good character, and have high social awareness. Education as the main route of human resource development and character building is the key word in determining the fate of the nation. Efforts to improve the quality of education in Indonesia have been carried out for a long time. In every long and medium term development plan, it is always stated that improving the quality of education is one of the development priorities in the field of education. Various innovations and educational programs have also been implemented, including improving the curriculum, procuring textbooks, improving the quality of teachers and other education personnel, improving education management, and providing other facilities.

Trilling et al. $(2009 ; 45-84)$ revealed that there are three skills that must be possessed to face the 21st century, namely life and career skills, learning and innovation skills and technology and information media skills. To improve the quality of skilled human resources for the $21^{\text {st }}$ century, the most effective method 
and the most appropriate choice is to improve the quality of national education. In this case the teacher becomes the foundation for improving the quality of national education which has skills in learning to face the $21^{\text {st }}$ century.

According to Trilling and Hood (1999) the main concern of education in the $21^{\text {st }}$ century is to prepare life and work for society. It is time to look for a moment to a broad perspective on the major roles that learning and education will increasingly play in a knowledgebased society. The decline in the quality of our education has been felt for years, for the umpteenth time the curriculum has always been blamed for the cause. We can examine this with the efforts to improve the curriculum starting from the 1975 curriculum to be replaced with the 1984 curriculum, then replaced again with the 1994 curriculum, not satisfied with the 1994 curriculum replaced with the 2004 curriculum which we know as Competency-Based Curriculum and refined again into the 2006 curriculum or what we like. familiar with the Education Unit Level Curriculum. Nasanius (1998) states that the decline without education is not caused by the curriculum but by the lack of professionalism of teachers and students' reluctance to learn. Professionalism as a supporter of the fluency of teachers in carrying out their duties is strongly influenced by two major factors, namely factors that include talent and external factors, namely those related to the surrounding environment, infrastructure and various exercises performed by teachers (Sumargi, 1996).

Binkley, et al (2010) present the $21^{\text {st }}$ century skills framework by grouping it into 1) ways of thinking, including creativity and innovation, critical thinking, problem solving, decision making, and metacognition, 2) how to work, which means communication and collaboration. or teamwork, 3) tools for work, including information literacy and information and communication technology literacy, and 4) life in the world, including citizenship, life and career skills, personal and social responsibility.

Basic teaching skills are a general characteristic of someone related to knowledge and skills that are manifested through action. Basically, basic teaching skills are in the form of basic and specific forms of behavior that a teacher must have as initial capital to carry out his teaching tasks in a planned and professional manner. The applicative indicators of basic teaching skills of $21^{\text {st }}$ century teachers can be described through nine teaching skills (Rusman, 2012). From the supporting theory, the problem formulation is how the skills of teaching teachers at Mataram City Junior High School in facing the $21^{\text {st }}$ century.

\section{Method}

This research is a descriptive study with the method of distributing questionnaires and interviews to SMPN teachers in Mataram as the sample. The sampling technique was random sampling, which was carried out across all junior high school science teachers in Mataram City with a total sample of 15 teachers. By using two types of data, namely qualitative and quantitative data (Creswell \& Clark, 2007). Qualitative research in the form of literature studies, needs analysis, and development of instruments summarized in an observation sheet of basic science teacher teaching skills and quantitative research in the form of data collection, data grouping, data quantization and data analysis. From the qualitative and quantitative research data, data interpretation was carried out and conducted a group discussion forum. The instrument for observing the basic teaching skills of science teachers contains eight skills with the criteria of being very good (5), good (4), sufficient (3), lacking (2), and very poor (1).

\section{Result and Discussion}

Distribution of basic teaching skills levels for junior high school science teachers based on teachers and types of skills

From the questionnaire data distributed, it can be seen that junior high school science teachers are very enthusiastic in teaching in accordance with the direct survey and very enthusiastic in filling out the questionnaire form that was distributed. The level of basic teaching skills for junior high school science teachers is in the range of 22 to 36 from the expectation score of 40 (five very good-skilled teachers (33.4\%), nine good-skilled teachers $(60 \%)$, and one moderately skilled teacher of $6.6 \%$ )

Teacher skills in each of the basic teaching skills of science teachers

The basic teaching skills of teachers in Mataram city vary widely. Data from the eight standards of basic teacher teaching skills can be seen in Table 1 .

Table.1 Teacher skill levels for each type of skill

\begin{tabular}{lll} 
No & Basic Teaching Skills & A scala score of 100 \\
\hline 1 & Opening Lessons & 63 \\
2 & Basic Questions & 55 \\
3 & Futher Questions & 48 \\
4 & Strengthening & 59 \\
5 & Explain & 46 \\
6 & Variation in Learning & 62 \\
7 & Discussion & 47 \\
8 & Closing & 57 \\
\hline
\end{tabular}


Judging from the types of basic teaching skills of junior high school science teachers, the skills to open lessons and the skills to do variations in teaching have a high level of skill, and the skills in explaining, small group discussion, and further questioning need to be improved again.

\section{The relationship between rank seniority and the level of basic teaching skills of science teachers}

The ranks of science teachers at Mataram city SMPN vary, from group III to group IV. Senior teachers (group IV) have a higher ability to use basic teaching skills than senior teachers (group III). The condition of the basic teaching skills of science teachers at this time, the result of the observation that the basic teaching skills of science teachers in general are $33.4 \%$ very good, $60 \%$ good and $6.6 \%$ sufficient.

According to Michael Dictop's Theory (in Rusman, 2012) to become an innovative teacher in the 21 st century or knowledge century there are 20 criteria, namely: (1) teachers are not easily satisfied with their additions and skills, strive to continue to improve their knowledge and skills. teaching, (2) the teacher always wants to know about something he does not know, especially new things for the benefit of his professional duties, (3) a sense of admiration for something new and has the motivation to develop himself, (4) farsighted and always sees going forward, (5) feeling that something is not impossible and can generate ideas beyond their mind, (6) dare to take risks and be willing to be in an uncomfortable situation, (7) constantly adjust to new work and problems, (8) dare to be different from others and have ideas that can attract the hearts of others, always share happiness with others, (8) be willing to maintain maintain the concept and idea, and consider the idea to be defended, (9) adapt to the situation and be open, (10) try to establish relationships with all levels, both superiors and subordinates, (11) assess the problems faced and seek solutions, (12) see things from a broad perspective. (13) do not panic easily in the face of a situation, (14) try to learn from time to time, especially with regard to science and technology, (15) make balanced judgments using the mind always assess and make analysis before making decisions, (16) try to balance thinking and always working together for the progress of their school, (17) communication is flexible and easy to understand, able to translate abstract things into something concrete, (18) to face obstacles steadfastly and learn from mistakes and not easily give up, (19) ) always work hard and diligently, (20) always provide ideas and a strong commitment to the field they do.

According to Makagiansar (1996) in the 2nd century the education system will experience a paradigm shift, namely a paradigm shift: (l) from terminal learning to lifelong learning, (2) from learning to focus on knowledge acquisition to helistic learning, (3) from image teacher-student relations that are confrontational to the image of a partnership relationship, (4) from teachers who emphasize academic knowledge to emphasize a balance of focus on value education, (5) from campaigns against illiteracy to campaigns against technology, culture, and computers, (6) from isolated teacher performance to performance in team work, (7) from exclusive concentration on competition to cooperation orientation.

The condition of the basic teaching skills of science teachers from the current observations of the eight basic teaching skills of junior high school science teachers, skills in opening lessons, and doing variations is very good, while the basic teaching skills of science teachers are explaining, small group discussions, and further questioning categories are at a sufficient level.

According to Naryo (2009), $21^{\text {st }}$ century teachers must master a lot of knowledge (academic, pedagogical, social and cultural), be able to think critically, be responsive to every change, and be able to solve problems. Nasanius (1998) states that the decline in education is not caused by the curriculum but by the lack of professionalism of teachers and students reluctance to learn, professionalism as a support for teachers' fluency in carrying out their duties, is strongly influenced by two major factors, namely internal factors which include interests and talents and external factors, namely related to the surrounding environment, infrastructure, as well as various exercises conducted by the teacher (Sumargi, 1996).

Observations of the basic teaching skills of junior high school science teachers show that the ability to apply basic teaching skills is very good for junior high school science teachers who are senior or already occupying the position of supervisor for Class $\mathrm{IV} / \mathrm{a}$ and above, while junior high school science teachers who are still senior (group III) show ability in applying basic teaching skills is still at a good level.

With regard to the importance of teacher professionalism in education in the 21st century, Sanusi et al, 1991 (in Rusman, 2012) state six assumptions that underlie the need for professionalization in $21^{\text {st }}$ century education, namely: (1) Educational subjects are humans who have the will, knowledge, emotions, and feelings and can be developed according to their potential; Meanwhile education is based on human values that respect human dignity; (2) Education is carried out intentionally, that is, consciously aimed, then education becomes normative which is bound by norms and values that are universal, national and local, which are 
the reference for educators, students and education managers; (3) Educational theories are answers to the hypothetical framework in answering educational problems ; (4) Education starts from a basic assumption about humans, namely that humans have good potential for development. Therefore, education is an effort to develop this superior potential ; and (5) The essence of education occurs in the process, namely a situation where there is a dialogue between students and educators which allows students to grow in the direction desired by the educator to be in line with the values upheld by society.

Often there is a dilemma between the main goal of education, which is to make humans a good human being (intrinsic dimension) and an instrumental mission, which is a tool for change or achieving something.

\section{Conclusion}

The results of the analysis of the basic teaching skills instrument and the analysis of the teacher's ability to plan a learning program can be concluded that the basic teaching skills of science teachers are generally $33.4 \%$ very good, $60 \%$ good and $6.6 \%$ sufficient. Of the eight basic teaching skills of junior high school science teachers, the skills to open lessons, do variations, and were very good, while the basic teaching skills of science teachers were explaining, small group discussions, and further questioning were sufficient categories. The ability to apply basic teaching skills is best done by junior high school science teachers who are senior or already occupying the position of supervisor for Category IV/a and above.

\section{References}

Binkley, M., Erstad, O., Herman, J., Raizen, S., Ripley, M., \& Rumble, M. (2010). Defining 21st century skills. Assessment and teaching of 21st century skills draft white paper. The University of Melbourne. Retrieved from: http://hdl.voced.edu.au/10707/260031

Creswell, J.W. \& Clark, V.L.P (2007) Mixed Methods Research. USA Sage Publication, Inc. Retrieved from: $\quad$ https://us.sagepub.com/enus/nam/mixed-methods-research/book241462

Galbreath, J. (1999). Preparing the 21st Century Worker: The Link between Computer-based Technology and Future Skills Sets. Educational Technology archive, 39, 14-22. Methods Research. USA Sage Publication, Inc. Retrieved from: https://www.jstor.org/stable/44428565?seq=1\# metadata_info_tab_contents
Greenstein, L. (2012). Assessing $21^{\text {st }}$ Century Skills. A Guide to Evaluating Mastery and Authentic Learning. United State of America: SAGE Publication. Retrieved from: https://us.sagepub.com/enus/nam/book/assessing-21st-century-skills

Hasan, M.A. (2003). Pengembangan Profestonalisme Guru di Abad Pengetahuan. Artikel Pendidikan. Retrieved from: $\underline{\text { ttp: } / / r e-}$ searchengines.comlarnhasan.html.

Makagiansar, M. (1996). Shift in Global paradigm and The Teacher of Tomorrow, 17th. Convention of the Asean Council of Teachers (ACT); 5-8 Desember, 1996, Republic of Singapore.

Naisbitt, J. (1995). Megatrend Asia: Delapan Megatrend Asia yang Mengubali Dunia, (Dubbed by Danan Triyatmoko dan Wandi S. Brata): Jakarta: Gramdeia.

Nasanius, Y. (1998). Kemerosotan Pendidikan Kita: Guru dan Siswa Yang Berperan Besar Bukcn Kurikulum. Jurnal, Retrieved from: (http://www.suarapembaharuan.com/News/19 8108/230898). Retrieved on 5 Maret 2018.

Naryo, W. (2009). Sosok Guru Abad 21, Sebuah Harapan dan Kenyataan. Retrieved from:: http://miftah19.wordpress.com2009/05/16/sos ok-guru-abad-2l-sebuah-harapan-dan-kenyataan.

Rusman. (2012). Belajar dan Pembelajaran Berbasis Komputer Mengembangkan Profesionalisme Abad 21. Bandung: AL: Fabet A, ev.

Sumargi. (1996). Profesi Guru Antara Harapan dan Kenyataan. Suara Guru No. 3-4/1996.

Surya, H.M. (1998). Peningkatan Profesionalisme Guru MenghadapiPendidikan Abad ke-2l; Organisasi \& Profesi. Suara Guru No.7/1998.

Trilling, B. \& Hood, P. (1999). Learning, Technology, and Education Reform. in the Knowledge Age or "We're Wired, Webbed, and Windowed, Now What"? Educational Technology. 